\title{
Alaskan Polar Bear Movements from Mark and Recovery
}

\author{
JACK W. LENTFER'
}

\begin{abstract}
Alaskan polar bear mark and recovery studies from 1967-1976 and concurrent studies elsewhere indicate some interchange of polar bears between Alaska and the mainland coast of northwest Canada, but not between Alaska and the rest of Canada, Greenland; and Svalbard. The extent of movement between Alaska and the U.S.S.R. remains unknown. The number of Alaskan bears. recovered in the same general area as marked suggests that the same animals tend to occur in the same general area in late winter and early spring each year. Distance traveled between marking and recovery sites and the proportion of animals that move to a different area are about the same for both sexes and for subadults and adults. Bears tend to disperse from commonly used areas in years when ringed seals are less available. The rate of movement in late winter and early spring is about the same for both sexes and for subadults and adults. After mid-April the predominant movement of bears north of Alaska is to the east.

Key words: polar bear, Alaska, Arctic, mark-recovery, movement

RÉSUMÉ. Des études de marquage et de repérage de l'ours blanc en Alaska entre 1967 et 1976 et d'autres études concomitantes effectuées ailleurs signalent un échange d'ours blancs entre l'Alaska et le littoral continental nord-ouest du Canada, mais non entre l'Alaska et le reste du Canada, le Groenland et le Svalbard. Le degré de mouvement entre l'Alaska et l'U.R.S.S. demeure inconnu. Le nombre d'ours blancs de l'Alaska reperés dans la même région générale dane laquelle ils ont été marqués suggère que ces mêmes animaux tendent à demeurer chaque année dans la même région générale en fin d'hiver et au début du printemps. La distance parcourue entre les sites de marquage et de repérage ainsi que la proportion des animaux qui se déplacent à une région différente sont à peu près. égales pour les deux sexes, comme pour les jeunes et les adultes. Les ours ont tendance à se disperser des régions fréquentées d'ordinaire lors des années durant lesquelles peu de phoques annelés se présentent. Les taux de mouvement est à peu près le même en fin d'hiver et en début de printemps, pour les deux sexes comme pour les jeunes et les adultes. Après la mi-avril, les ours au nord de l'Alaska se déplacent surtout vers l'est.
\end{abstract}

Mots clés: ours blanc, Alaska, Arctique, marquage-repérage, déplacement

Traduit pour le journal par Maurice Guibord.

\section{INTRODUCTION}

Polar bear numbers and distribution can be affected by hunting and habitat alteration. In order to properly regulate these activities in and offshore from Alaska, managers must know if Alaskan polar bears are part of one circumpolar. population (Pedersen, 1945), or form one or more subpopulations, either shared jointly with adjoining countries or confined to Alaska. Managers should also understand movement patterns of bears. Lentfer (1974) concluded that polar bears west and north of Alaska tended to form subpopulations with only a limited amount of interchange. Stirling et al. (1981) stated that exchange between the western Canadian Arctic and Alaska was restricted to bears caught along the mainland coast, with no exchange recorded between Banks Island in Canada and the Point Barrow area of Alaska.

Movement information has been obtained for Alaskan polar bears by marking and then resighting and recapturing animals, and by recovering tags from bears killed by hunters. Alaskan studies were concurrent with similar studies in Canada, U.S.S.R., Greenland, and Svalbard.

This paper, based on an Alaskan mark and recapture program from 1967-76, indicates that Alaskan polar bears are not part of one circumpolar population, but have some degree of interchange with northwestern Canada. The same individual animals tend to return to the same general Alaskan area in late winter and early spring each year.

\section{METHODS}

Polar bears on sea ice located from aircraft between 1 March and 10 May were immobilized for examination and marking by injecting phencyclidine hydrochloride (Sernylan) with a syringe gun from a helicopter. They were marked with ear tags, lip tattoos, and numbers dyed on the fur (Lentfer, 1968). From 1967-1976, 809 bears were captured for the first time, 94 of these were recaptured one or more times, and 53 were taken by hunters (Lentfer et al., 1980).

Movement information was obtained by resighting and recapturing animals and from tags and tattoos on bears killed by hunters. Before passage of the federal Marine Mammal Protection Act of 1972, game regulations of the State of Alaska required hunters to present polar bear skulls and skins to Game Department representatives for examination; data were then recorded for marked animals. After 1972, hunters were not required to report kills, and information on marked animals was obtained from them on a voluntary basis.

Ages of cubs, yearlings, and two-year-olds were usually determined by body size. Occasionally, yearling males were distinguished from two-year-old females by degree of canine tooth eruption. Older bears were assigned ages based on tooth cementum layering, tooth wear, body measurements, and indicators or reproductive status (Hensel and Sorensen, 1980).

Alaskan studies were coordinated with those of other countries, partly through the Polar Bear Specialist Group organized within the International Union for the Conservation of Nature. This prevented duplication of marks and provided for immediate exchange of information on capture and marking techniques and bear movements. Polar bear mark and recovery programs in other countries provided means of recovering Alaskan bears and also provided marked animals which could be recovered in Alaska. Numbers of bears marked in other locations during this same general period

\footnotetext{
${ }^{1}$ Alaska Department of Fish and Game, 230 South Franklin Street, Juneau, Alaska 99801, U.S.A., and Institute of Medical Biology and Department of Arctic Biology, University of Troms 6 , Box 635, 9001 Troms 6 , Norway
} 


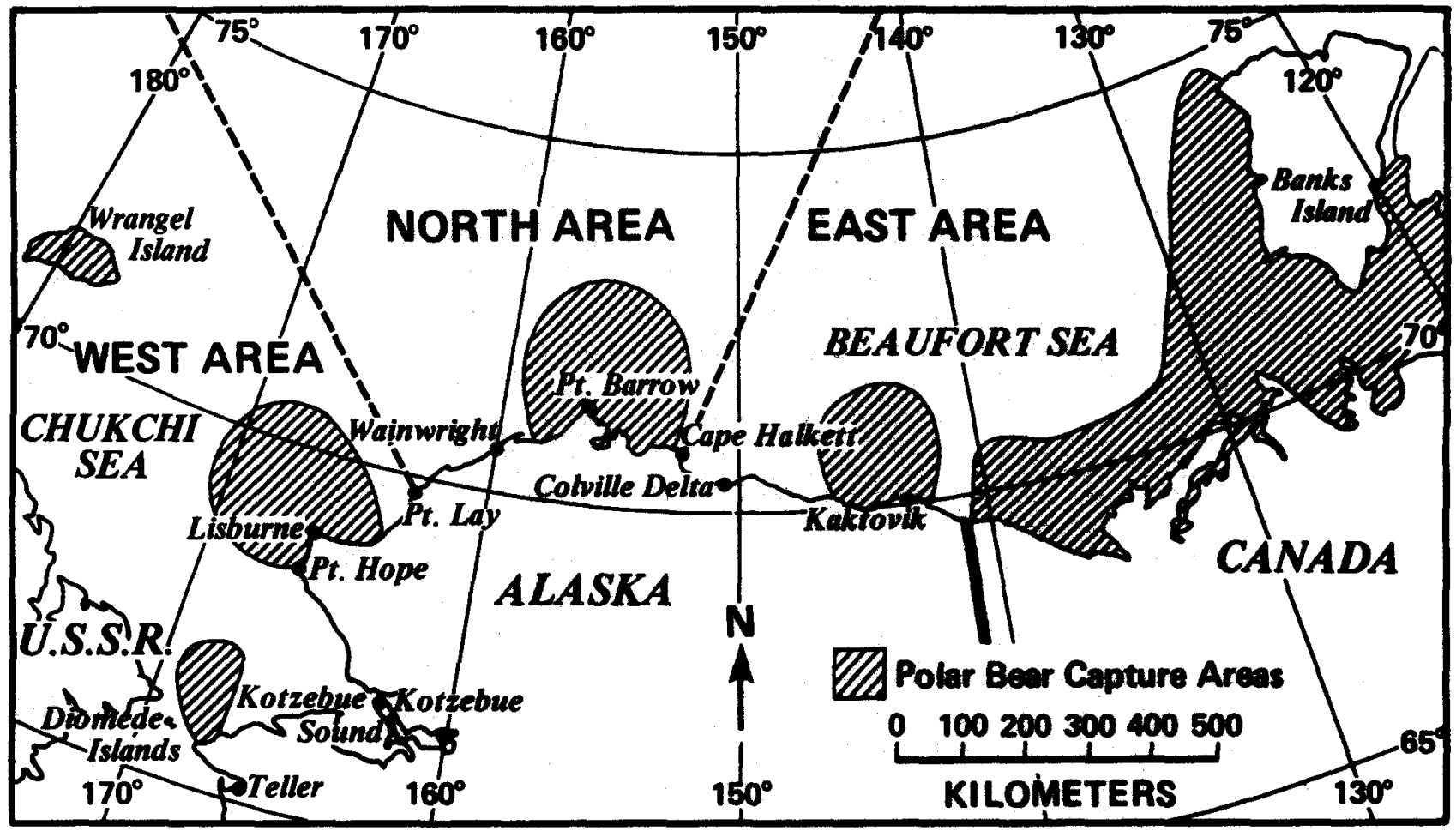

FIG. 1. Map of northern Alaska.

were: 149 - Wrangel Island, U.S.S.R. (Uspenski and Belikov, 1976; Uspenski et al., 1980); 605 - northwest Canada (Stirling et al., 1981); 914 - high and lower central Canadian Arctic Islands (Stirling et al., 1978); 231 southeast Baffin Island, Canada (Stirling et al., 1980); 227 Manitoba, Canada (Stirling et al., 1977b); 49 - northern Labrador, Canada (Stirling and Kiliaan, 1980); 43 - east Greenland (Vibe, 1982); 103 - Svalbard (Larsen, 1971). Hunting also provided a means for recovery of marked bears in Canada, Greenland, and through 1973 in Svalbard.

Bears were marked in four Alaskan areas (Fig. 1). Recovery information came from these same four areas for recaptured bears and from much of the offshore Alaskan area for bears killed by hunters. Airplanes could be used as an aid to hunting through 1972, and some bears were taken as far as $450 \mathrm{~km}$ offshore from Alaska. The main bases for hunters using aircraft were Teller, Kotzebue, Point Hope, Barrow, Colville Delta, and Kaktovik (Barter Island). Shore-based hunting was primarily from Little Diomede Island, Point Hope, Wainwright, Barrow, and Kaktovik.

Lentfer (1974) defined two Alaskan areas, west and north, as having populations that were somewhat discrete, with a line extending northwest from Point Lay as the arbitrary division between them. A third (east) area was added for the present analysis. The separation between north and east areas extends north from Cape Halkett (Fig. 1).

Analysis of recovery of marked animals required an estimate of the number of marked animals in the population. This was obtained by applying a factor of $12 \%$ for annual tag loss and bear mortality (Lentfer et al., 1980).

Movement data were of two types: recaptures and hunter returns nine months or more after capture, and single-season resightings and hunter returns three months or less after capture. Analysis for fidelity to an area was based only on recoveries after nine months. Each interval between capture or resighting and the next capture, resighting, or kill by a hunter was considered a separate movement.

Data were examined to determine whether recovered animals were randomly mixed throughout the area where Alaskan bears occur, or if they were more likely to be recovered in the area where they were last captured. If marked animals distributed themselves randomly throughout the Alaskan polar bear area, then at any specific tag and recovery location, the ratio of tags recovered which had been applied at that location to the total tags recovered at that location would be the same as the ratio of tags applied at that location and available for recovery to the total tags available for recovery throughout the entire Alaskan polar bear area (Table 1). For example, assume that after natural mortality and tag loss, the Alaskan population in 1975 contained 600 bears that had been marked before 1974, 400 of which had been marked in the north area. Further assume that in 1975, 18 marked bears were recovered in the north area, 12 of which had also been marked in the north area. The ratio of marked animals (north/total) is the same for both total marked animals and recovered animals, and indicates complete mixing of marks throughout the general population. However, if 16 of the 18 recovered animals had been marked in the north area, this would show that more marked animals were recovered in the north area than expected with random mixing and would indicate a tendency for animals to remain in or return to the area.

Another method for examining whether marked bears were 
randomly mixed was to compare the actual number of animals marked and then recaptured in the same area with the number to be expected, relative to capture effort and to the total number of marked animals from that area that were recaptured at all locations. For example, in a given year, if 20 animals that had been previously marked in the north area were recaptured at all locations, and if $60 \%$ of the capture effort was in the north area, then with random mixing of marked animals, it could be expected that $60 \%$, or 12 , of the marked animals would be recaptured in the north area. Recapture in the north area of more than 12 animals that had been marked there would indicate a tendency for bears to stay in or return to that area.

Data were also examined for sex and age differences in average distance between capture and recovery locations and in proportion of recovered animals that had moved to a different area. Data for bears that had moved between Canada and Alaska were included with data for movements only within Alaska when determining and comparing average length of movements. Movement data from Canada to Alaska were not included when determining the proportion of bears moving to a different area, since this would have required analysis of Canadian data.

To examine data for sex-age differences in average distance from marking site to recovery site, animals of each sex were grouped into two categories. The subadult category included animals through four years of age when marked that were recovered when three to five years old. Cubs, yearlings, and two-year-olds captured during the first part of the tagging season accompanied adult females, and their recovery distances were not included. The adult category included animals that were marked at five years of age and older. Not included in either category were animals marked as cubs, yearlings, two-year-olds, and subadults and then recovered as adults, because their movements occurred when they were both subadults and adults. A third category for each sex included all animals recovered after about 28 months of age; data for younger animals were not included since they still accompanied adult females.

Data on distance between capture and recovery sites did not fit a normal distribution well; a Wilcoxon two-sample test, which does not require a normal distribution, was therefore used to examine sex differences in mean recovery distances for subadults, adults, and subadults and adults combined. A Wilcoxon two-sample test was also used to examine age differences in mean recovery distances by comparing subadult males with adult males and with adult females, and by comparing subadult females with adult females and with adult males. Difference between numbers of males and females and between numbers of subadults and adults that moved to a different area were examined by $2 \times 2$ contingency table analyses.

For short-term, single-season movements, rate of movement was calculated as the number of $\mathbf{k m}$ per day between capture or resighting location to the next resighting or kill location. Direction of movement was designated as the nearest 45-degree main compass direction, i.e. north, northeast, east, etc.

To determine whether the rate of movement differed between subadults and adults and between sexes, the mean number of $\mathrm{km}$ per day for each of the four groups (subadult [3-5 y/o] and adult [ $>5 \mathrm{y} / \mathrm{o}]$ males and females) was compared with each of the others. Data were also examined for direction of movement. This was by visual inspection for west and east areas. The primary question for the north area was whether animals were moving predominantly east or west to a different area adjacent to the coast. Therefore, the number of northeast, east, and southeast movements were combined and compared with the total number of northwest, west, and southwest movements. Lentfer (1974) reported that bears in the north area move east in late April and May, and movements before and after 15 April were therefore grouped separately. Differences in frequencies of animals moving to the west and to the east were examined by Chi-square analysis.

\section{FINDINGS}

During the period of the study, 1967-1976, the only known movements of marked polar bears into or out of Alaskan territory were between Alaska and the eastern Beaufort Sea off the mainland of northwest Canada, and between Alaska and Wrangel Island off the northeast coast of the U.S.S.R. Nine marked animals from the Barrow area and two from the Barter Island area moved to the Canadian Beaufort Sea area during this period. Four marked animals moved from the Canadian Beaufort Sea area to the Barrow area, and two moved from the Canadian Beaufort Sea area to the Barter Island area. The 13 movements between Barrow and Canada were the longest recorded $($ mean $=750 \mathrm{~km}$, range $=584-1018 \mathrm{~km}$ ). Seven of these 13 recoveries occurred two years after tagging and two occurred one year after tagging. Recovered animals included both sexes, and young, subadult, and adult animals. Of the six Canadian bears recovered in Alaska, five were recovered in 1975 and one in 1976, following the extreme reduction in ringed seals and polar bears in the Canadian Beaufort area that occurred between the springs of 1974 and 1975 (Stirling et al., 1975,1977 a). Bears marked in Alaska were recovered in Canada prior to 1974 and after 1975, but not in 1974 and 1975.

Soviet biologists captured a marked female with cubs in a den on Wrangel Island in the spring of 1976. She had a broken ear tag and could be identified only to the extent of determining that she had been marked in Alaska or Canada. The only movement recorded from Wrangel Island was by an adult female, accompanied by yearling cubs when marked at Wrangel Island in the spring of 1979; she was killed by a hunter at Wainwright, Alaska, in the fall of 1980.

Table 1 shows numbers of marked animals and recovered animals by capture and recovery areas during each year of the study. Recovery effort was not the same in all areas, and Table 1 cannot be used to assess fidelity to or movement from an area. 
TABLE 1. Number of marked Alaskan polar bears by area where marked, assuming $12 \%$ annual mark loss from bear mortality and disappearance of marks, and long-term (nine months or longer) movements of recovered animals, 1968-1977

\begin{tabular}{|c|c|c|c|c|c|c|c|c|c|}
\hline & \multirow{2}{*}{\multicolumn{3}{|c|}{$\begin{array}{l}\text { Marks in population } \\
\text { by area applied }\end{array}$}} & \multicolumn{6}{|c|}{ Movement for recovered marks } \\
\hline & & & & \multicolumn{2}{|c|}{$\mathrm{W}$ to } & \multicolumn{3}{|c|}{$\mathbf{N}$ to } & \multirow{2}{*}{$\frac{\mathrm{E} \text { to }}{\mathrm{N}}$} \\
\hline & $\mathrm{W}^{*}$ & $\mathbf{N}$ & $\mathbf{E}$ & $\mathbf{W}$ & $\mathbf{N}$ & $\mathbf{W}$ & $\mathbf{N}$ & $E$ & \\
\hline 1968 & & 27 & & & & & 2 & & \\
\hline 1969 & 53 & 94 & & 1 & 2 & 3 & 4 & & \\
\hline 1970 & 53 & 102 & 2 & 2 & 1 & & 6 & & \\
\hline 1971 & 70 & 138 & 2 & 2 & 2 & 2 & 4 & 1 & \\
\hline 1972 & 81 & 167 & 1 & 2 & 1 & 1 & 20 & & \\
\hline 1973 & 123 & 231 & 1 & & & & & & \\
\hline 1974 & 108 & 204 & 1 & & 6 & 1 & 17 & & \\
\hline 1975 & 95 & 283 & 1 & 1 & & 2 & 11 & 1 & \\
\hline 1976 & 84 & 282 & 32 & & & 5 & 21 & & 1 \\
\hline
\end{tabular}

*W, N, and E refer to west, north, and east areas (Fig. 1).

Table 2 presents total number of polar bears recovered in west and north areas by year, number of bears recovered in -same area as marked, and number expected to be recovered in same area as marked if complete mixing of marked animals occurred. Numbers are low for the west area and data do not provide definite conclusions, but for four of the seven years, more animals that were marked in the west area were recovered there than would be expected if random mixing occurred. Sample sizes are larger for the north area, and for six of the seven years, more animals that were marked in the north area were recovered there than would be expected if complete mixing of marked animals occurred. Too few bears were recovered in the east area for a similar analysis.

Table 3 compares the number of bears captured and recaptured in the north area with the number of recaptures expected if all marked bears distributed themselves randomly throughout the population. For five of the six years for which there are data for this type of analysis, more bears that had been captured in the north area were recaptured there than would be expected if marked bears were randomly distributed throughout the population after a year, indicating a tendency for individual animals to remain in or return to the north area. Too few bears were recaptured in west and east areas to provide similar analyses for these areas.
TABLE 3. Number of Alaskan polar bears marked in north area and then recaptured, and expected recapture in north area, based on capture effort, if marked animals were randomly distributed in population

\begin{tabular}{ccccc}
\hline & $\begin{array}{c}\text { Total north } \\
\text { marks recaptured } \\
\text { all locations }\end{array}$ & $\begin{array}{c}\text { North capture } \\
\text { effort/Total } \\
\text { capture effort }\end{array}$ & $\begin{array}{c}\text { North marks recaptured } \\
\text { in north }\end{array}$ \\
$\begin{array}{ccccc}\text { Expected with } \\
\text { random mixing }\end{array}$ & Actual \\
\hline 1968 & 2 & $82 / 142$ & 1.2 & 2 \\
1970 & 5 & $59 / 87$ & 3.4 & 5 \\
1971 & 2 & $53 / 76$ & 1.4 & 1 \\
1972 & 8 & $105 / 165$ & 5.1 & 8 \\
1975 & 10 & $47 / 83$ & 5.7 & 9 \\
1976 & 21 & $76 / 129$ & 12.4 & 18 \\
\hline \hline
\end{tabular}

Differences between sexes for average distance between capture and recovery sites were not significant when comparisons were made between male and female subadults, between male and female adults, and between males and females of all ages combined other than cubs, yearlings, and two-yearolds still with adult females (Table $4, P>0.05$ in all cases). Differences between subadults and adults in average distance between capture and recovery locations were not significant when subadult males were compared with adult males and with adult females, and when subadult females were compared with adult females and with adult males (Table 4, P>0.05 in all cases).

Table 5 shows numbers of subadult and adult males and females that were recovered in the same and in different areas than were marked. It appears that proportionately more males and adults may have moved to different areas, and simple contingency table analyses were used to test for possible age and sex effects. Each of four groups (subadult and adult males and females) was compared with each of the other groups, and sex and age effect were treated together in a 3-way model with the area category. In no instance was significance observed at the $5 \%$ level.

Single-season movements of 1-58 days were recorded between 2 March and 20 May. Movements for all animals were in the same area as marked, except for one four-year-old male marked in the west area on 12 March and resighted $493 \mathrm{~km}$

TABLE 2. Number of marked polar bears recovered west and north of Alaska and expected recovery if all bears were randomly mixed throughout Alaskan polar bear area

\begin{tabular}{|c|c|c|c|c|c|c|}
\hline & \multicolumn{3}{|c|}{ West area } & \multicolumn{3}{|c|}{ North ares } \\
\hline & \multicolumn{2}{|c|}{ Actual } & \multirow{2}{*}{$\begin{array}{l}\text { Expected from } \\
\text { west areas if } \\
\text { all marks } \\
\text { randomly mixed }\end{array}$} & \multicolumn{2}{|c|}{ Actual } & \multirow{2}{*}{$\begin{array}{l}\text { Expected from } \\
\text { north areas if } \\
\text { all marks } \\
\text { randomly mixed }\end{array}$} \\
\hline & $\begin{array}{l}\text { From all } \\
\text { marking } \\
\text { locations }\end{array}$ & $\begin{array}{l}\text { From } \\
\text { west } \\
\text { area } \\
\end{array}$ & & $\begin{array}{l}\text { From all } \\
\text { marking } \\
\text { locations }\end{array}$ & $\begin{array}{c}\text { From } \\
\text { north } \\
\text { area } \\
\end{array}$ & \\
\hline 1969 & 4 & 1 & 1.4 & 6 & 4 & 3.8 \\
\hline 1970 & 2 & 2 & 0.7 & 7 & 6 & 4.7 \\
\hline 1971 & 4 & 2 & 1.3 & 6 & 4 & 3.9 \\
\hline 1972 & 3 & 2 & 1.0 & 21 & 20 & 14.1 \\
\hline 1974 & 1 & 0 & 0.3 & 23 & 17 & 15.0 \\
\hline 1975 & 3 & 1 & 0.8 & 11 & 11 & 8.2 \\
\hline 1976 & 5 & 0 & 1.1 & 22 & 21 & 15.6 \\
\hline
\end{tabular}


TABLE 4. Distance $(\mathrm{km})$ from capture site of Alaskan polar bears to next capture or kill site after an interval of at least nine months

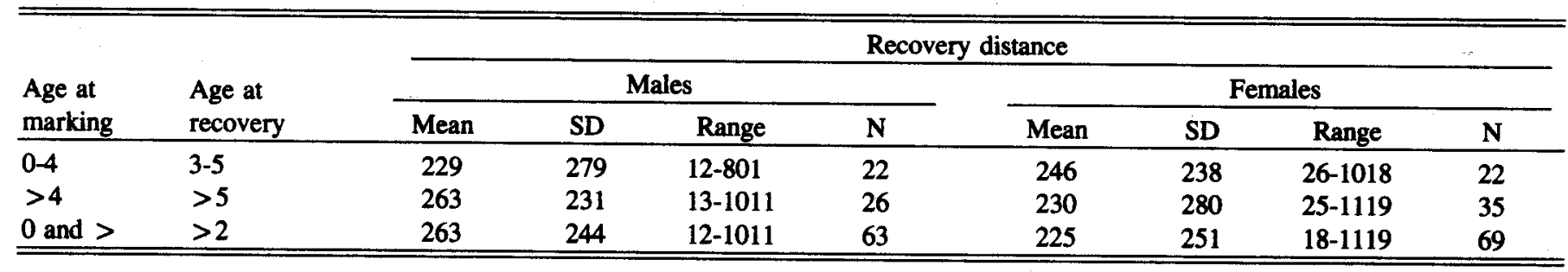

TABLE 5. Numbers of marked Alaskan polar bears recovered in same area as marked and in different area from where marked

\begin{tabular}{|c|c|c|c|c|c|}
\hline \multirow[b]{2}{*}{$\begin{array}{l}\text { Age when } \\
\text { marked }\end{array}$} & \multirow[b]{2}{*}{$\begin{array}{l}\text { Age when } \\
\text { recovered }\end{array}$} & \multicolumn{2}{|c|}{ Males } & \multicolumn{2}{|c|}{ Females } \\
\hline & & $\begin{array}{c}\text { Same } \\
\text { area }\end{array}$ & $\begin{array}{c}\text { Different } \\
\text { area }\end{array}$ & $\begin{array}{c}\text { Same } \\
\text { area }\end{array}$ & $\begin{array}{c}\text { Different } \\
\text { area }\end{array}$ \\
\hline $0-4$ & $3-5$ & 14 & $7(33 \%)$ & 16 & $4(20 \%)$ \\
\hline$>4$ & $>5$ & 17 & $9(35 \%)$ & 24 & $10(29 \%)$ \\
\hline 0 and $>$ & $>2$ & 42 & $20(32 \%)$ & 50 & $16(24 \%)$ \\
\hline
\end{tabular}

away in the north area on 10 May. This was the longest singleseason movement recorded.

The mean rate of movement for all bears was $10.7 \mathrm{~km} \cdot \mathrm{d}^{-1}$ (Table 6). No significant difference was observed in rate of movement between four groups (subadult and adult males and females) when each group was compared with each of the others $(P>0.05$ in all cases).

The west area had 19 and the east area had 10 resightings. In both areas, movements were not predominantly in any one direction. The north area had 92 resightings, 40 in an easterly (northeast, east, southeast) direction, 34 in a westerly (northwest, west, southwest) direction, and 18 to the north or south. For movements through 15 April, 14 were easterly and 17 were westerly. For movements after 15 April, 17 were to the east and 6 to the west. The only period when the frequency of easterly movements differed significantly from westerly movements was after 15 April $(P<0.05)$.

TABLE 6. Rate of movement $\left(\mathrm{km} \cdot \mathrm{d}^{-1}\right)$ of Alaskan polar bears from capture or resighting location to next resighting or kill location during single season (less than three months)

\begin{tabular}{lrrrlllllll}
\hline & \multicolumn{4}{c}{ Males } & & \multicolumn{4}{c}{ Females } \\
\cline { 2 - 4 } \cline { 7 - 9 } Age & Mean & SD & Range & N & & Mean & SD & Range & N \\
\hline $3-5$ & 7.3 & 8.8 & $0.7-40.3$ & 31 & & 8.2 & 9.2 & $0.4-36.3$ & 26 \\
$>5$ & 12.3 & 11.7 & $0.4-40.5$ & 20 & & 13.1 & 13.9 & 0 & -72.0 & 46 \\
\hline \hline
\end{tabular}

\section{DISCUSSION}

All marking of polar bears in this study and nearly all recoveries of marked animals, both by recapturing and from hunters, have been in the March-May period, and data therefore show movement from one late winter - early spring period to another. During the early part of this period, bears are distributed along the Alaskan coast from Bering Strait north and northeastward to the Canadian border, with the exception of Kotzebue Sound. During heavy ice years, some bears move south of Bering Strait into the northern Bering Sea. In summer, bears stay with the ice, which may recede as far as $200 \mathrm{~km}$ north of Point Barrow and further offshore elsewhere. Because bears make this extensive summer movement associated with location of ice, recovery data for the late winter and early spring show return to an area or movement to a new area, but do not give an indication of total movement throughout the year.

The present study and concurrent mark and recovery studies in northwest Canada (Stirling et al., 1975, 1981) show some movement of polar bears between Alaska and the mainland coastal area of northwest Canada. Lack of recovery of marked animals in the present study and in studies in other locations indicates no movement of animals between Alaska and Svalbard, Greenland, and Canada other than the northwest mainland coastal area (Larsen, 1971; Stirling et al., 1977b, 1980; Stirling and Kiliaan, 1980; Schweinsburg et al., 1981, 1982; Vibe, 1982). In the U.S.S.R., the only reported mark and recapture effort has been on Wrangel Island off the northeast coast of the U.S.S.R. There may be some interchange of animals between Alaska and Wrangel Island but more work is needed to determine the extent. The degree of interchange, if any, between Alaska and the rest of the U.S.S.R. has not been determined.

The United States, along with the other four countries which have jurisdiction for polar bears (U.S.S.R., Norway, Denmark, and Canada), is signatory to the 1973 Oslo Agreement on Conservation of Polar Bears. The Agreement calls for cooperation in management of polar bear populations that are shared by two or more nations. Probably the greatest shared management concern for Alaska is possible environmental impact from oil and gas exploration and development by the U.S. and Canada in the Beaufort Sea. Activities that affect bears in one country could affect bears in the other country because there is some exchange of animals. Also, oil from a Canadian spill or blowout that contaminates polar bear habitat could affect Alaska since the prevailing ocean current is from east to west.

No physical barriers to polar bear movement exist along or offshore from the Alaskan coast from Bering Strait to the Canadian border, and winter habitat (except in Kotzebue Sound) is suitable for bears along this section of coast and offshore for at least $200 \mathrm{~km}$, as evidenced by presence of bears. Data are lacking on distribution and movements of bears during the summer, but concentrations of bears along the southern edge of the ice pack and movements of currents and ice could cause mixing of animals. As might be expected under these 
conditions, recovery of marked animals does not indicate welldefined discrete subpopulations. However, limited data do indicate that bears tend to be recovered during late winter and early spring of subsequent years more in the same general area where marked than in other areas. This is similar to geographic seasonal fidelity reported for polar bears in northwest Canada (Stirling et al., 1981), Lancaster Sound, Canada (Schweinsburg et al., 1982), the lower central Arctic Islands of Canada (Schweinsburg et al., 1981), Churchill area, Canada (Stirling et al., 1977b), and Svalbard (Larsen, 1971). Evidence other than mark and recovery also suggests that Alaskan polar bears are not a single, homogeneous population with complete mixing of animals. Bears in the area west of Alaska have larger skulls and bodies than bears in the area north of Alaska (Manning, 1971; Lentfer, 1974; Wilson, 1976). Bears in the area north of Alaska have significantly higher total mercury residue levels in tissue than those in the area west of Alaska (Lentfer, 1976).

Bears probably disperse from commonly used areas when ice conditions reduce availability of ringed seals, their main food. As an example, in March and early April of 1971, ice in the north study area was predominantly multi-year with exceptionally few open and recently frozen leads. Ringed seals were less evident and there were fewer polar bears than in years when ice conditions were more normal. During the same period, the west study area had about the same interspersion of multi-year ice, young ice, and open water as in most years. Seals were common and bears more abundant than most years, suggesting that animals had moved from the north toward the west area. Following storms and high winds in mid-April, the ice in the north area became more open, seals were evident, and bears were present again in good numbers, suggesting that bears respond quickly to local habitat changes.

The only recoveries in Alaska of bears that had been marked in Canada were in 1975 and 1976, following extreme reductions in ringed seals and polar bears that occurred in the Canadian Beaufort area between the springs of 1974 and 1975 (Stirling et al., 1975, 1977). Bears marked in Alaska were recovered in Canada in 1973 and 1976, but not in 1974 and 1975 , the period when seals were low in numbers. This again shows that availability of seals influences movement of bears.

The mean distance from capture site to recovery site was greater for males than for females and for subadults than for adults. However, variances were large and differences were not statistically significant. Similar comparisons between numbers of animals recovered in the same area as where tagged and in a different area than where tagged showed a greater proportion of males than of females moving to a different area. Again, however, differences were not statistically significant. These findings are similar to those of the lower central Arctic Islands of Canada where Schweinsburg (1981) found that distances moved by different age classes and sexes of recaptured polar bears did not differ significantly.

Similarly, for the present study, the rate of movement during a single season did not differ significantly between sexes and between subadults and adults. Great variation among in- dividuals occurred, with one-day movements ranging from 0 to $72 \mathrm{~km}$.

In conclusion, polar bear marking studies show some interchange of animals between Alaska and the mainland coast of northwest Canada, but not between Alaska and the rest of Canada, Greenland, and Svalbard. Limited data from recovery of marked animals suggest that the same bears tend to occur in the same general Alaskan area in late winter and early spring each year. Sex and age differences are not apparent in distances traveled between marking and recovery sites and in the proportion of animals that move to a different area. Bears tend to disperse from commonly used areas in years when ringed seals are less available. The rate of movement in late winter and early spring is about the same for males and females and subadults and adults. After mid-April the predominant movement of bears north of Alaska is to the east.

The U.S. may share a polar bear population with the U.S.S.R. in the Chukchi Sea, but more studies are needed to determine the extent of polar bear movement between Alaska and the U.S.S.R. Studies should include three to five years of intensively marking and recapturing polar bears along the northeast coast of the Siberian mainland, on Wrangel Island, and off Alaska's northwest coast. It would be important to determine movement patterns of bears that den on Wrangel Island, a high-density maternity denning area. It would also be of interest to determine if females born on Wrangel Island return there as adults to den and produce young.

Mark and recovery studies do not provide information on movement throughout the year, which is needed to precisely describe discreteness of populations. Such information can probably be obtained only by radio-tracking polar bears from an earth-orbiting satellite.

\section{ACKNOWLEDGEMENTS}

Field work was funded by the Alaska Department of Fish and Game Federal Aid in Wildlife Restoration Program and the U.S. Fish and Wildlife Service. The help of many members of both agencies and of aircraft pilots who assisted in the field is gratefully acknowledged. At the University of Troms $\phi$, Asle Balsvik assisted with computer programming and Erik Bolviken with statistics. Ian Stirling and Ray Schweinsburg provided critical reviews of the manuscript.

\section{REFERENCES}

HENSEL, R.J. and SORENSEN, F.E. 1980. Age determination in live polar bears. In: Martinka, C.F. and McArthur, K.L. (eds.). Bears - Their Biology and Management. Washington, D.C.: U.S. Government Printing Office. 93-100.

LARSEN, T. 1971. Capturing, handling and marking polar bears in Svalbard. Journal of Wildlife Management 35:27-36.

LENTFER, J. 1968. A technique for immobilizing and marking polar bears. Journal of Wildlife Management 32:317-321.

1974. Discreteness of Alaska polar bear populations. International Congress of Game Biologists 11:323-329.

1976. Environmental contaminants and parasites in polar bears. Alaska Federal Aid in Wildlife Restoration Final Report. 22 p.

, HENSEL, R.J., GIL BERT, J.R. and SORENSEN, F.E. 1980. Population characteristics of Alaskan polar bears. In: Martinka, C.J. and McArthur, K.L. (eds.). Bears - Their Biology and Management. Washington, D.C.: U.S. Government Printing Office. 109-115. 
MANNING, T.H. 1971. Geographical variation in the polar bear Ursus maritimus. Canadian Wildlife Service Report Series No. 13. 27 p.

PEDERSEN, A. 1945. Der Eisbar; Verbreitung and Lebenweise. Copenhagen: E. Bruun and Co. $166 \mathrm{p}$.

SCHWEINSBURG, R.E., FURNELL, D.J. and MILLER, S.J. 1981. Abundance, distribution and population structure of polar bears in the lower Central Arctic islands. Northwest Territories Wildlife Service Completion Report No. 2. 80 p.

SCHWEINSBURG, R.E., LEE, L.J. and LATOUR, P.B. 1982. Distribution, movement, and abundance of polar bears in Lancaster Sound, Northwest Territories. Arctic 35:159-169.

STIRLING, I., ANDRIASHEK, D. and CALVERT, W. 1981. Habitat preferences and distribution of polar bears in the western Canadian Arctic. Report for Dome Petroleum Limited, Esso Resources Canada Limited, and the Canadian Wildlife Service. $49 \mathrm{p}$.

STIRLING, I., ANDRIASHEK, D. LATOUR, P and CALVERT, W. 1975. The distribution and abundance of polar bears in the eastern Beaufort Sea. A Final Report to the Beaufort Sea Project. Victoria, B.C.: Fisheries and Marine Service, Department of the Environment. $59 \mathrm{p}$.

STIRLING, I., ARCHIBALD, W.R. and DEMASTER, D. 1977a. Distribution and abundance of seals in the eastern Beaufort Sea. Journal of the Fisheries Research Board of Canada 34:976-988.

STIRLING, I., CALVERT, W. and ANDRIASHEK, D. 1980. Population ecology studies of the polar bear in the area of southeastern Baffin Island. Canadian Wildlife Service Occasional Paper No. 44. 33 p.

STIRLING, I., JONKEL, C., SMITH, P., ROBERTSON, R. and CROSS, D. $1977 \mathrm{~b}$. The ecology of the polar bear (Ursus maritimus) along the western coast of Hudson Bay. Canadian Wildlife Service Occasional Paper. No. $33.64 \mathrm{p}$.

STIRLING, I. and KILIAAN, H.P.L. 1980. Population ecology studies of the polar bear in northern Labrador. Canadian Wildlife Service Occasional Paper No. $42.21 \mathrm{p}$.

STIRLING, I., SCHWEINSBURG, R.E., CALVERT, W. and KILIAAN, H.P.L. 1978. Population ecology of the polar bear along the proposed Arctic Islands Gas Pipeline Route. Final Report to the Environmental Management Service, Department of the Environment. Edmonton, Alberta. $93 \mathrm{p}$.

USPENSKI, S.M. and BELIKOV, S.E. 1976. Research on the polar bear in the USSR. In: Lentfer, J.W., Pelton, M.R. and Folk, G.E. (eds.). Bears - Their Biology and Management. International Union for Conservation of Nature Publication New Series 40:321-323.

and KUPRIYANOV, A.G. 1980. Polar bear research and conservation in the USSR, 1975-1976. Proceedings of Sixth and Seventh Working Meetings of the IUCN Polar Bear Specialist Group. Gland, Switzerland: International Union for Conservation of Nature. 178-186.

VIBE, C. 1982. Gronlands hvibe bjorne. Naturens Verden 2:41-56.

WILSON, D.E. 1976. Cranial variation in polar bears. In: Pelton, M.R., Lentfer, J.W. and Folk, G.E. (eds.). Bears - Their Biology and Management. International Union for Conservation of Nature Publication New Series 40:447-453. 